\title{
Mangrove environmental services and local livelihoods in Vietnam
}

Pham Thu Thuy'

\section{Key messages}

- Mangroves not only play an important role in climate change adaptation and mitigation, but also provide natural, social, human, financial and physical capital for local livelihoods in Vietnam.

- Successful mangrove conservation policies and projects need to address drivers of mangrove loss, enhance all five forms of sustainable livelihood capital for local people, and adopt inclusive and participatory decision making.

- Equitable benefit-sharing mechanisms and mutually beneficial and trust-based collaboration between stakeholders are also needed.

\section{Introduction}

Mangroves play an important role in climate change adaptation and mitigation and local livelihoods in Vietnam (Orchard et al. 2015c). The mean value of mangrove ecosystems could be up to USD 3,000/ha/year in Vietnam (Vo et al. 2015). However, population growth and political changes have driven mangrove loss (Quinn et al. 2017) and Vietnam's mangroves are currently being poorly managed with neither clear technical guidelines nor adequate financial support (Thai and Nguyen 2020). Using a sustainable livelihood framework developed by DFID and a literature review of government and donor reports as well as scientific studies on mangroves and local livelihoods, this paper assesses the five forms of capital natural, physical, social, financial and human capital - that mangroves can bring to local people in Vietnam.

\section{Mangroves and local livelihoods}

Natural capital: Mangrove ecosystems offer natural capital such as hydrological services for the country and for local people (Barbier 2011). To protect mangroves and local livelihoods, the Government of Vietnam has allocated areas of mangrove to local communities under protection contracts. This forestland allocation has helped increase natural capital for many communities in Vietnam.
However, poor implementation of these contracts due to communities' lack of legal understanding, inadequate guidance on mangrove planting and restoration techniques, and the small areas of mangroves allocated to local people (commonly under one hectare) have led to negative impacts on mangrove natural capital (McElwee and Tran 2021; Nguyen, Thai and Parnell 2017). In fact, most tree planting in Vietnam, including mangrove planting, creates very few social and ecological benefits (McElwee and Tran 2021).

Physical capital: Mangroves can act as green fences protecting communities against storm surges and climate change (Chu et al. 2015; Tran et al. 2021). Mangrove ecosystem services can also play an important role in generating and increasing infrastructure, housing and property market value (World Bank 2016). If current mangroves were lost, 29\% more land and 9\% more property would be damaged every year (Menéndez et al. 2020). Mangroves prevent annual property losses of at least USD 500 million for Miami in the USA and Cancun in Mexico (Menéndez et al. 2020). There has been no systematic review of the economic contributions of mangroves on properties in Vietnam, and investment in residential and tourism development has recently been approved in the buffer zone of the Can Gio Mangrove Biosphere Reserve in Ho Chi Minh City (Belmaker 2020). 
Social capital: To respond to climate change and climate shocks, coastal communities need to have adequate social networks (Orchard et al. 2015b; Djalante et al. 2013). In Vietnam, a 10\% increase in social capital can increase a community's earnings by 3.9\% (Duong et al. 2021). Co-management regimes, where local communities partner government agencies, are one form of social network expected to improve local livelihood and mangrove protection outcomes (Powell et al. 2011). However, cooperation between aquaculture producers and local governments is often limited (Nguyen et al. 2020). The absence or weak presence of civil society has been identified as a challenge to helping local communities participate in mangrove management decision making (Orchard et al. 2015). Moreover, sub-national government agencies fail to bridge gaps between local people and central government due to weak capacity, insufficient budget allocation, contradictory cross-sectoral policies and unclear distribution of rights and responsibilities (Pham et al. 2009; Hoang and Takeda 2015). Mangrove governance is also impeded by weak performance and not meeting the needs of local communities (Tran et al. 2021). Land privatization and migration from coastal to urban areas further deprive local communities of livelihoods as they reduce the possibility of maintaining and extending the existing social capital embedded in community resources management (Le 2008; Pham et al. 2019). Factors affecting coastal households' participation in social networks include educational background, age, duration of residence and population density (Duong et al. 2021). Coastal communities and households who depend on mangroves for their livelihoods may have limited capacity to respond to shocks and climate change if those mangroves are lost. Little recognition is afforded to women in mangrove governance, and as women are rarely involved in decision-making networks, this leads to gender inequality (Orchard 2014).

Financial capital: Mangroves provide different sources of income for many households in Vietnam (Orchard et al. 2015b). The most important source of income from mangroves for local communities is aquaculture production. Previous studies in the Mekong Delta have documented that one hectare of mangroves can support annual catches of $450 \mathrm{~kg}$ (de Graaf and Xuan 1998), and that 30\%-50\% mangrove cover in aquaculture production areas is likely to bring optimum annual incomes for local people (Binh et al. 1997). On average, a household can earn up to USD 50 a day for small-scale fishing or aquaculture (Pham et al. 2019). People can also receive payments of up to USD 15/ha under mangrove protection and planting contracts through international and government projects (Nguyen et al. 2016). Mangroves can also be tourist destinations and in many areas people can earn up to USD 21.7 a day by providing tourism services (Nguyen 2020). Hence, declines in mangrove area have led to reduced household incomes (de Graaf and Xuan 1998). Vietnam is currently exploring options for payments for mangrove environmental services, which include carbon sequestration. However, local people will only benefit if the costs to other land uses are not too high, and actual gains will depend on payment amounts and the area of mangroves households manage (Pham et al. 2019). Economic benefits derived from mangroves also depend on land ownership (Adger et al. 1997). Although forestland allocation aims to support local communities and households, allowing them to benefit from forest management (Tran, van Dijk and Visser 2014), as the area of mangroves allocated to households in the north of the country is relatively small compared to those in the south, any incomes generated from forest protection or carbon sequestration will likely be higher in the south. State agencies, as holders of the largest areas of mangroves, will benefit the most. Meanwhile, coastal fishing communities are vulnerable due to weak legal access to mangrove resources, high investment costs, unstable markets, and climate change (Tran et al. 2013).

Human capital: If mangrove areas are lost, more than 15 million more people across the world will be negatively impacted by flooding (Menéndez et al. 2020). Previous studies in Vietnam have shown that poor households participate in mangrove conservation more effectively than rich households as they believe mangroves can protect their families (Pham et al. 2016). Thanks to many international and national mangrove restoration projects, local people have been trained in aquaculture production, alternative livelihood souces and sustainable forest management (Asian Forest Cooperation Organization, Programs 2015; Mangroves for the Future 2021). Incomes derived from mangrove resources can also help coastal households invest in their children's education. Despite mangroves playing an important role for women in providing a source of firewood and income (Pham et al. 2019), increased allocation of mangroves to private businesses has impacted upon poor households, and particularly women (Le 2006).

\section{Discussion and conclusions}

As mangroves play an important role in local livelihoods in Vietnam, increasing effort has been invested in their replanting and protection. Nevertheless, as government agencies only perceive and apply mangrove restoration as a technical solution, these initiatives often overlook local perceptions of mangroves as cultural and livelihood sources (Hoang and Takeda 2015). Further, while local people are often blamed for mangrove deforestation, mangrove loss is often rooted in national economic development goals and driven by power and elite groups (Pham et al. 2019). To address mangrove loss and promote sustainable and equitable mangrove resources management, appropriate policies should be developed that promote local livelihoods, focus on ensuring social benefits for local people, and regulate economic sectors and activities that harm mangroves (McElwee and Tran 2021; Le 2008). 
To protect mangroves and improve local livelihoods in a more sustainable manner, it is important to facilitate the establishment and maintenance of social networks for coastal communities through collaboration, and trust in local capacity and self-organization (Orchard et al. 2015). However, this might be challenging due to an uneven distribution of adaptive capacity, limited resources and limited rights for women to access mangrove resources, as well as elite capture and the lack of inclusive decision making (Orchard 2014).

Addressing political and social challenges, empowering local people with adequate rights and resources, strengthening law enforcement, and designing inclusive decisionmaking processes are critical for both mangroves and local livelihoods.

\section{Acknowledgement}

This research was funded by the United States Agency for International Development (USAID) through the Sustainable Wetlands Adaptation and Mitigation Program (SWAMP) and the CGIAR Research Program on Forests, Trees and Agroforestry (FTA).

\section{References}

Adger W, Kelly M, Nguyen H and Ngo C. 1997. Property rights and the social incidence of mangrove conversion in Vietnam. Cserge Gec working paper.

Asian Forest Cooperation Organization. Programs \& Projects 2015. Landmark Program: Rehabilitation \& development of mangrove forest ecosystem in Thai Binh province, Viet Nam. Viewed 26 July 2021. Available from: http://afocosec.org/ rehabilitation-and-development-of-mangrove-forestecosystem-in-thai-binh-province-viet-nam/

Barbier E. 2011. Wetlands as natural assets. Hydrological Sciences Journal, 56(8), pp. 1360-1373.

Beck MW and G-M. Lange G-M. eds. 2016. Managing coasts with natural solutions: Guidelines for measuring and valuing the coastal protection services of mangroves and coral reefs. Wealth Accounting and the Valuation of Ecosystem Services Partnership (WAVES), World Bank, Washington DC. Belmaker G. 2020. Vietnam approves $\$ 9$ billion development within mangrove reserve. Mongabay Environmental News. Viewed 25 July 2021. Available from: https://news. mongabay.com/2020/08/vietnam-approves-9-billiondevelopment-within-mangrove-reserve/

Binh C, Phillips M and Demaine H. 1997. Integrated shrimpmangrove farming systems in the Mekong Delta of Vietnam. Aquaculture Research, 28(8), pp. 599-610.

Chu V, Brown S, To H and Hockings M. 2015. Using Melaleuca fences as soft coastal engineering for mangrove restoration in Kien Giang, Vietnam. Ecological Engineering, 81, pp. 256-265. de Graaf $G$ and Xuan T. 1998. Extensive shrimp farming, mangrove clearance and marine fisheries in the southern provinces of Vietnam. Mangroves and Salt Marshes, 2, pp. 159-166.

Djalante R, Holley C, Thomalla F and Carnegie M. 2013. Pathways for adaptive and integrated disaster resilience. Natural Hazards, 69(3), pp. 2105-2135.

Duong T, Trinh Q, Thai H, Berg H and Da T. 2021. Assessment of the impacts of social capital on the profit of shrimp farming production in the Mekong Delta, Vietnam. Aquaculture Economics \& Management, pp. 1-19.

Hoang $\mathrm{H}$ and Takeda S. 2015. Decentralization in mangrove restoration: A critical analysis-case study in Central Coast of Vietnam. In An international academic conference, Chiang Mai University: Land grabbing, conflict and agrarian-environmental transformation: Perspectives from East and Southeast Asia. Conference Paper. No. 50, p. 17.

Le H. 2008. Economic reforms and mangrove forests in Central Vietnam. Society \& Natural Resources, 21(2), pp. 106-119.

Le T. 2006. Gender, doi moi and mangrove management in Northern Vietnam. Gender, Technology and Development, 10(1), pp. 37-59.

Mangroves for the Future. 2021a. Capacity building in management and conservation of mangroves ecosystem in a community participatory approach in Mui Ca Mau National Park. Viewed 26 July 2021. Available from: http://www. mangrovesforthefuture.org/grants/small-grant-facilities/ viet-nam/cycle-2-sgf-projects-vn/capacity-building-inmanagement-and-conservation-of-mangroves-ecosystemin-a-community-participatory-approach-in-mui-ca-maunational-park/

Mangroves for the Future. 2021 b. Viet Nam. Viewed 26 July 2021. Available from: http://www.mangrovesforthefuture. org/countries/members/viet-nam/

McElwee P and Tran H. 2021. Assessing the social benefits of tree planting by smallholders in Vietnam: Lessons for large-scale reforestation programs. Ecological Restoration, 39(1-2), pp. 52-63.

Menéndez P, Losada I, Torres-Ortega S, Narayan S and Beck M. 2020. The global flood protection benefits of mangroves. Scientific Reports, 10(1).

Nguyen H, Tran D, Luan P, Ho L, Loan V, Anh Ngoc P, Quang N, Wyatt A and Sea W. 2020. Socio-ecological resilience of mangrove-shrimp models under various threats exacerbated from salinity intrusion in coastal area of the Vietnamese Mekong Delta. International Journal of Sustainable Development \& World Ecology, 27(7), pp. 638-651.

Nguyen T. 2020. Livelihoods transformed with mangrove forest protection. Vietnam Investment Review - VIR. Viewed 25 July 2021. Available from: https://vir.com.vn/livelihoodstransformed-with-mangrove-forest-protection-80781.html. Nguyen T, Nguyen V, Le P and Parnell K. 2016. Community perspectives on an internationally funded mangrove restoration project: Kien Giang province, Vietnam. Ocean \& Coastal Management, 119, pp. 146-154. 
Nguyen T, Thai T and Parnell K. 2017. Mangrove allocation for coastal protection and livelihood improvement in Kien Giang province, Vietnam: Constraints and recommendations. Land Use Policy, 63, pp. 401-407.

Orchard S, Stringer L and Quinn C. 2015a. Environmental entitlements: Institutional influence on mangrove socialecological systems in Northern Vietnam. Resources, 4(4), pp. 903-938.

Orchard S, Stringer L and Quinn C. 2015b. Impacts of aquaculture on social networks in the mangrove systems of northern Vietnam. Ocean \& Coastal Management, 114, pp. 1-10.

Orchard S, Stringer L and Quinn C. 2015c. Mangrove system dynamics in Southeast Asia: Linking livelihoods and ecosystem services in Vietnam. Regional Environmental Change, 16(3), pp. 865-879.

Orchard S. 2014. Exploring adaptive capacity in mangrove social-ecological systems of rural Vietnam. [PhD thesis] University of Leeds.

Pham T and Yoshino K. 2016. Impacts of mangrove management systems on mangrove changes in the Northern Coast of Vietnam. Tropics, 24(4), pp. 141-151.

Pham T, Vu T, Pham D, Dao L, Nguyen V, Hoang N, Hoang T, Dao T and Nguyen D. 2019. Opportunities and challenges for mangrove management in Vietnam: Lessons learned from Thanh Hoa, Thai Binh and Quang Ninh provinces. Occasional Paper 197. Bogor, Indonesia: CIFOR.

Powell N, Osbeck M, Sinh B and Vu C. 2011. World Resources Report Case Study. Mangrove restoration and rehabilitation for climate change adaptation in Vietnam.
World Resources Report, Washington DC. Viewed 25 July 2021. Available from: https://citeseerx.ist.psu.edu/viewdoc/ download?doi=10.1.1.1070.6865\&rep=rep1\&type=pdf.

Quinn C, Stringer L, Berman R, Le H, Msuya F, Pezzuti J and Orchard S. 2017. Unpacking changes in mangrove socialecological systems: Lessons from Brazil, Zanzibar, and Vietnam. Resources, 6(1), p. 14.

Thai T and Nguyen T. 2020. Current management of allocated mangroves for livelihood improvement in the Mekong Delta, Vietnam: Knowledge gaps and a potential model for future management. Journal of Sustainable Forestry, 40(1), pp. 68-82.

Tran T, van Dijk H and Visser L. 2014. Impacts of changes in mangrove forest management practices on forest accessibility and livelihood: A case study in mangroveshrimp farming system in Ca Mau province, Mekong Delta, Vietnam. Land Use Policy, 36, pp. 89-101.

Tran T, van Dijk H, Bosma R and Le X. 2013. Livelihood capabilities and pathways of shrimp farmers in the Mekong Delta, Vietnam. Aquaculture Economics \& Management, 17(1), pp. 1-30.

Tran V, Nguyen T and Pham T. 2021. Governance of mangrove ecosystems in Northern Vietnam with consideration of impacts of sea level rise and climate change: A dynamic approach. Natural Resource Governance in Asia, pp. 99-133.

Vo T, Kuenzer C and Oppelt N. 2015. How remote sensing supports mangrove ecosystem service valuation: A case study in Ca Mau province, Vietnam. Ecosystem Services, 14, pp. 67-75.

\begin{tabular}{|l|l|l|l|l} 
The CGIAR Research Program on Forests, Trees and Agroforestry (FTA) is the world's largest research \\
for development program to enhance the role of forests, trees and agroforestry in sustainable \\
development and food security and to address climate change. CIFOR leads FTA in partnership with \\
ICRAF, the Alliance of Bioversity International and CIAT, CATIE, CIRAD, INBAR and TBI. \\
FROGRAM ON \\
Forests, Trees and work is supported by the CGIAR Trust Fund: cgiar.org/funders/
\end{tabular}

\section{USAID \\ FROM THE AMERICAN PEOPLE}

\section{Center for International Forestry Research (CIFOR)}

CIFOR advances human well-being, equity and environmental integrity by conducting innovative research, developing partners' capacity, and actively engaging in dialogue with all stakeholders to inform policies and practices that affect forests and people. CIFOR is a CGIAR Research Center, and leads the CGIAR Research Program on Forests, Trees and Agroforestry (FTA). Our headquarters are in Bogor, Indonesia, with offices in Nairobi, Kenya; Yaounde, Cameroon; Lima, Peru and Bonn, Germany. 